(Al Adawiah et al)

\title{
Effect of Place and Time Storage on the Quality of Tubers Amorphophallus muelleri Blume
}

\author{
Putri Rabiah Al Adawiah, Rodiyati Azrianingsih*, Retno Mastuti
}

Department of Biology, Faculty of Mathematics and Natural Sciences, University of Brawijaya, Malang, Indonesia

\begin{abstract}
Porang tubers are plant commodities that physiologically susceptible to damage. Longtime storage can decrease the quality of tubers. Furthermore, the presence of fungi or bacteria makes tubers cannot be stored in a long time. Decreasing quality of Porang tuber became a problem because of the higher demand for Porang tubers. This research was conducted to determine the suitable place and time storage of Porang tubers. Therefore, farmers can control or reduce the decrease in tuber quality. Methods of this research were an observation of color change based on the Munsell Color System, odor observation, hardness observation using penetrometer, the rotten area of tuber was measured using Leaf Area Meter, shrinkage of tuber weight, the percentage of rotten and sprouted tubers, density, and moisture content by the oven method. The results of this study were analysed statistically by ANOVA test. The hardness of the tubers has a significant effect on the storage place (soil, rack, and floor) for period 14 weeks. Storage time has an effect on changes of the weight loss, moisture content and decay area. The longer the tuber stored the higher percentage of sprouted and rotten tubers. The color of Porang tubers changed and the odour in the part of the rotten tubers increased during the storage period in each storage place. Porang tubers should be stored than two weeks and placed on a rack to minimize the damage of the tubers.
\end{abstract}

Keywords: Amorphophallus oncophyllus, lles-iles, Physical change, Yellow konjac

\section{INTRODUCTION}

Porang (Amorphophallus muelleri Blume) is a plant commodity that belongs to the Araceae family and an indigenous plant with stump tubers in the soil. Porang tubers have high economic value due to their glucomannan content which has many benefits such as for the industries of foods, cosmetics, pharmacies and manufactures. Besides that, porang tubers have been often processed into flour which has frequently used as a thickening agent. As the increases utilization of Porang tubers, the demand for Porang tubers rapidly rises year to year [1].

For fullfilling the demand, however, Porang farmers have problems in handling postharvest tubers which are susceptible to decay. The decay can be indicated by the change in shape, colour, texture, and nutritional content [2]. Common characters of Porang tuber damage are wrinkles, porous, split tubers, and blackened tubers. If porang tubers do not handle properly, the quality of tubers decreases, so that the selling price of tubers also decreases [3].

Based on previous studies, storage place and period have affected on the quality of sweet potatoes, potatoes, and some other tubers. Storage of tuber crops using good methods was

\footnotetext{
"Correspondance address

Rodiyati Azrianingsih

Email: rodiyati@ub.ac.id

Address: Dept. Biology, University of Brawijaya, Veteran Malang, Malang 65145.
}

able to reduce postharvest damage [4]. The length of storage of tubers should be considered because during the storage, water evaporation took place affecting tubers lose a lot of water and the texture of tubers softens. Besides that, there was a compound that are influenced, one of those were starch and sugar [5]. The starch was reduced to sugar catalyzed by the phosphorylase enzyme. Consequently, the amount of starch in the tuber decreased resulting soften tuber [6], then this condition ease the tubers to be damaged [7]. The product quality is very important to be concerned as consumers need. Therefore recommendation of storage place and period is required for maintaining tuber quality.

Bantur is one of the Porang centre farm in Indonesia. Based on observations, most farmers keep the crop on the ground or floor without any special treatment. It can accelerate the decomposition of Porang tubers with erratic storage time. The limited tools for processing porang tubers into flour also cause people to process porang tubers without any option for storage. Therefore, this research was aimed to determine the suitable place and time storage of Porang tubers.

\section{MATERIAL AND METHODS}

This research was conducted in August to November 2017. Tubers were collected from Porang farm in Rejosari Village, Bantur, Malang. Tubers were treated 1 week after harvest and selected 72 fresh tubers with no physically 
damaged when harvesting with weight 800 1.900 grams. Storage of porang tubers was carried out at the Garden Palma Housing in Malang City.

Tubers were stored using three storage methods as follows: placed on dry soil with a little gravel (S), placed on a rack made of bamboo $(R)$, and placed on the tile floor (F). Each storage place consists of 24 tubers divided into three replications so that each replication consists of 8 tubers. Storage time was designed for 14 weeks, with observations every two weeks. Storage space in semi-open space, the condition of the

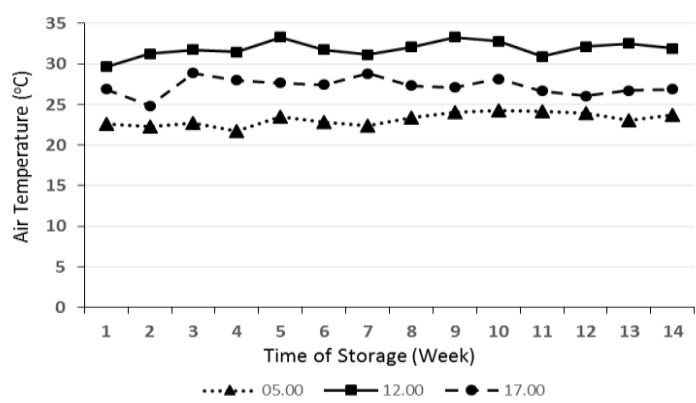

room include temperature and air humidity recorded using the Blynk program http://blynk.ub.ac.id/microclimate.php (Fig. 1).

\section{Research Design}

This research was conducted using a randomized block design with three replication as a group. Replication of tuber samples divided into two groups. Replication 1 and 2 were observed in the first week, while replication 3 was observed in the second week. Due to the gradual harvest, the tuber sample from farmers cannot be taken all together.

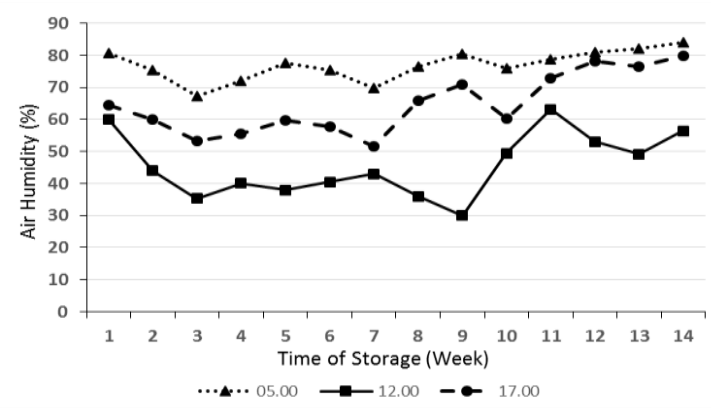

Figure 1. Temperature $\left({ }^{\circ} \mathrm{C}\right)$ and humidity $(\%)$ in storage time

\section{Observation on Physical Characteristics of Rotten Tuber Symptoms}

The first observation of the morphological characters of tuber rotten symptoms was the colour change of the parts of tubers that experienced rotten tuber (black, brown, white, etc.). Colour changes were determined using a colour table (the Munsell Color System). Odour changes were observed then chategorized as (A) very sting odour, (B) sting odour, and (C) not sting odour.

Hardness was observed by checking the level of tuber softness or hardness using a penetrometer [8], the tubers were placed below the penetrometer piercing needle. The stabbing was done on the tubers 10 times in ten places, the results of each stab are indicated by numbers on the penetrometer scale. The rotten area of tubers measured by using a millimeter paper attached to the tuber area, then marked using a pen and measured using a Leaf Area Meter apparatus.

\section{Percentage of Rotten Tubers and Tubers Sprout}

Percentage of decayed tubers and sprout tubers were calculated in every storage period. The percentage of tubers is counted every two weeks during storage using the formula:
Rotten tuber presentation $(\%)=\frac{\text { Number of rotten tubers }}{\text { Total tubers }} \times 100 \%$

The percentage of sprouting tuber is counted every two weeks during the storage period:

Sprouts tuber presentation $(\%)=\frac{\text { Number of sprout tubers }}{\text { Total tubers }} \times 100 \%$

\section{Weight Loss of Tubers}

The mass of all sample tuber was weighted. Percentages of weight loss were determined by the formula [5]:

Weight loss $(\%)=\frac{\text { Tuber weight } \mathrm{msp} 0-\text { Tuber weight } \mathrm{msp}-\mathrm{n}}{\text { Tuber weight } \mathrm{msp} 0} \times 100 \%$

\section{Water Content Analysis}

Tuber was $10 \mathrm{~g}$, then it was dried in the oven at $105^{\circ} \mathrm{C}$ for 24 hours, and then it was dessicated for 15 minutes until the weight was constant. Determination of water content was calculated by the following formula [8].

Water content $(\%)=$

$\frac{\text { Mass the tubers before the oven }(\mathrm{g}) \text {-Mass the tubers after the oven }(\mathrm{g})}{\text { Mass the tubers before the oven }(\mathrm{g})} \times 100 \%$

\section{RESULT AND DISCUSSION}

Effect of Parameters on Storage Time, Storage Space and Their Correlation

There was significant influence between parameters, storage period, storage area and only hardness have interaction between storage 
time (TS) and place (PS) (Table 1). Based on the correlation test between parameters, there were correlations that influence each other (Table 2).

\section{Morphological Character Changes (Colour and Stink)}

Damage symptoms occured in Porang tubers stored for fourteen weeks of storage on the ground, rack, or floors. The surface of tuber damage was performed as wrinkled and porous. The damage was followed by varying color changes during storage followed by the appearance of concomitant white fungus and maggots. These color changes include dry brown (5YR3/4), wet brown, and wet black. The defective part of the tuber has an unpleasant odor, the longer storage time the odor is more stinging (Fig. 2).

The mechanism of porang tuber decay is thought to be related to its existence Polyphenol oxidases (PPO) enzymes and polyphenolic compounds, include tannins, causes brownish colour in the tubers if there is direct contact with oxygen in the air $[9,10]$. The enzyme comes out if there is a wound on the tuber [11]. PPO catalyses the oxidation reaction of phenolic compounds to quinones which are further polymerized into dark-coloured melanin pigments [12].

When the tubers are injured, the parenchymal tissue in the tubers thickens the cell wall. It is also affected by the presence of bacterial pectolytic enzymes which are capable of destroying the binding material between cells. The presence of microorganisms that come in direct contact with storage or in the air can affect changes in commodity quality during storage, as explained by Purwanti [13] in potato tubers, discoloration occurs due to the presence of pathogenic bacteria such as Citrobacter, Phytophthora infestans, and Erwinia carotovora. Citrobacter bacteria are able to produce PCDE (Plant Cell Wall Degrading Enzymes) which can degrade cell walls. It causes damage to the cell wall and organelles to come out, then mucus appears. The appearance of a musty odour by fat oxidation produces carbonyl compounds that react with oxygen in the air [14].

Table 1. Test of interactions between parameters, time storage and place storage

\begin{tabular}{cccccccccc}
\hline \multirow{2}{*}{ Parameter } & \multicolumn{3}{c}{ Time storage (TS) } & \multicolumn{3}{c}{ Place Storage (PS) } & \multicolumn{2}{c}{ TS vs PS } \\
\cline { 2 - 9 } & d.f & F & Sig. & d.f & F & Sig. & d.f & F & Sig. \\
\hline Hardness & 7 & $29.343^{* *}$ & .000 & 2 & $23.338^{* *}$ & .000 & 14 & $1.991^{*}$ & .039 \\
Decay area & 7 & $6.442^{* *}$ & .000 & 2 & $1.737(\mathrm{~ns})$ & .187 & 14 & $.717(\mathrm{~ns})$ & .747 \\
Shrink Weight & 7 & $13.356^{* *}$ & .000 & 2 & $.375(\mathrm{~ns})$ & .690 & 14 & $1.452(\mathrm{~ns})$ & .167 \\
Water content & 7 & $5.627^{* *}$ & .000 & 2 & $1.922(\mathrm{~ns})$ & .157 & 14 & $1.054(\mathrm{~ns})$ & .421 \\
\hline
\end{tabular}

Notes: (Sig > $0.05=$ not significant), ${ }^{*}<0.05 ; * *<0.01$

Table 2. The correlation between parameters

\begin{tabular}{lcccccc}
\hline \multicolumn{1}{c}{ Parameter } & Hardness & Rotten area & \% rotten & \% sprout & Shrink Weight & Water content \\
\hline Hardness & & $-502 * *$ & $-594^{* *}$ & $-595^{* *}$ & $-659^{* *}$ & $.285^{*}$ \\
Rotten area & $-502 * *$ & & $.687 * *$ & $.679 * *$ & $.463^{* *}$ & $-345^{* *}$ \\
Percentage of rotten tuber & $-596 * *$ & $.689 * *$ & & $.994 * *$ & $.589 * *$ & -158 \\
Percentage of sprouted tuber & -595 & $.679 * *$ & $.994 * *$ & & $.581^{* *}$ & -163 \\
Shrink Weight & $-659 * *$ & $.463^{* *}$ & $.591^{* *}$ & $.581^{* *}$ & & $-384 *$ \\
Water content & $.297^{*}$ & $-354 * *$ & -158 & -163 & $-384 * *$ & \\
\hline
\end{tabular}

Notes: (Sig > $0.05=$ not significant), ${ }^{*}<0.05 ; * *<0.01$
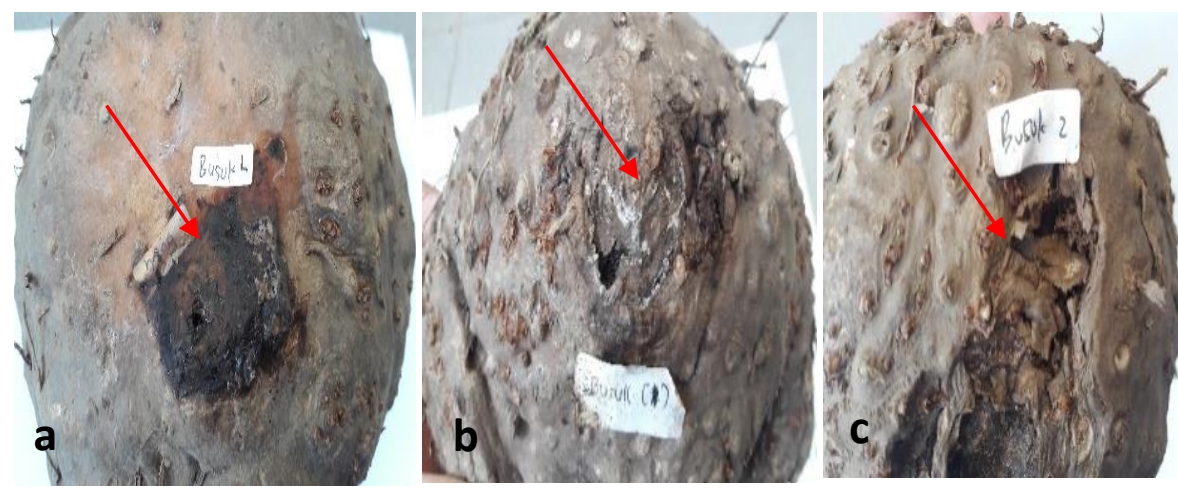

Figure 2. Rotten tubers: (a) Aqueous rot, (b) A runny rot performing white fungus around the rotten area, (c) Dry rot. 
The highest damage of tubers occurred in the area that is directly contacted with the storage place due to less air circulation, such as on the floor and soil. The presence of pathogens in the soil serves as a source that starts the rot. Poor air circulation causes heat buildup and increases moisture as a result of respiration therefore inducing spores and pathogenic growth. Storage on the rack was the best storage because the rotten in tuber is slower because there is sufficient air circulation that can reduce heat buildup and high humidity levels [15].

\section{Hardness of Tubers (mm. $\mathrm{g}^{-1}$. seconds ${ }^{-1}$ )}

The hardness of tubers during storage decreased gradually (Fig. 3). The decrease in hardness was first seen in the fourth week (W-4). The highest decrease was on the floor, then on the soil and rack. The variation in rotten tuber during storage in the following weeks tend to be harder. It may be affected by activation of respiration overhauled starch to glucose.

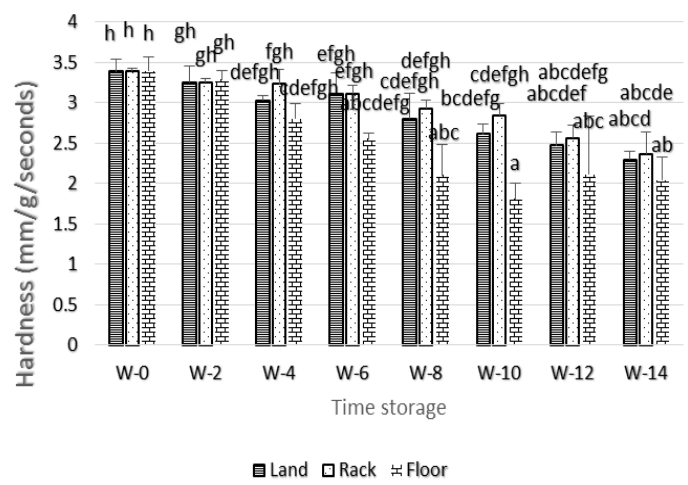

Figure 3. Tuber hardness values during storage times at three storage places. Different letters indicate differences among storage times within storage places. Vertical lines represent the Standard Deviation (SD) of the means across three replicates.

The glucose coud be consumed by pathogens, then remodeled into ethanol and water $\left(\mathrm{H}_{2} \mathrm{O}\right)$. This process decreases the hardness of tubers. However, the hardness of the tuber stored on the floor increased in W-12 and W-14 because transpiration process reduces the water content in the tuber, then tubers became harder.

Hardness is caused by starch granules that are tightly arranged in the tubers, if the granules in the tubers are high, the penetrometer needle is rather difficult to penetrate into the tubers. The longer the storage, the lower of hardness [8]. Hardness changes can be caused by the transpiration process which causes water loss during storage and effects wrinkling. It made the products less attractive because of the decreased quality [16].

Changes in hardness during the storage period may be also affected by changes in cell wall compounds. The cell wall became simpler that weaken the cell wall and bond cohesion between tissues. In normal tubers, starch granules are tightly arranged so that the texture of the tubers is hard (normal) [5]. Based on the correlation test, hardness of porang tubers were also influenced by several parameters, namely the size of rotten area, the percentage of decayed tubers, the percentage of germinated tuber, the weight loss and the water content of tuber (Table 2).

\section{Spots of tubers rotten area}

The area size of tuber rot during storage increased (Fig. 4). The tubers softened gradually and the rotten area size was wider. However, there was a decrease in rotten area at the tenth week (W-10) and twelfth week (W-12) due to variation in rotten symptoms in each week of observation. At the first tubers showed runny rot but some weeks after storage the tubers became dry (shrinking) so the rotten area decreased. Increasing the size of rotten areas could facilitate greater water loss, causing shrinkage of the tubers during storage.

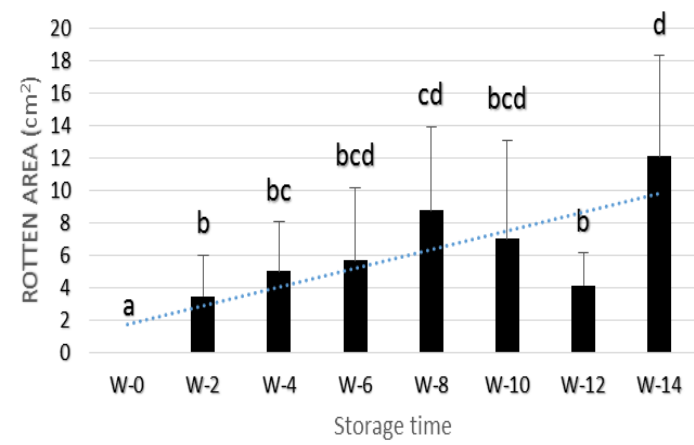

Figure 4. Size of rotten area $\left(\mathrm{cm}^{2}\right)$ of porang tubers during storage. Different letters indicate differences among storage times. Vertical lines represent the Standard Deviation (SD) of the means across nine replicates.

The size of rotted area of tuber increased during storage. Based on the correlation test, the symptom had negative correlation with hardness and water content. But, it had positive correlation with the percentage of rotten tuber, percentage of sprouted tuber, and weight loss (Table 2). Damage of the porang tubers appeared firstly on their small part of tuber skin. The physical damage is commonly found to tuber commodities indicating the decrement of tuber 
quality. The tuber skin functions as a barrier or protector from bacterial or fungal attacks. If the skin is damaged, infection by pathogenic microorganisms will expand [16]. Fresh porang tubers were naturally starting to demage shorter after storage.

\section{Percentage of Rotten and Sprout Tubers}

The percentage of rotten tuber and sprouted tubers during storage increased in this study (Fig. $5)$. In the second week (W-2), the tubers stored on the ground, the rack and floors started to be rotten and sprouted. In the fourth week (W-4) until the sixth week (W-6), the percentage of rotten and germinated tubers increased, then at the eighth week (W-8), all tubers in the three storage places were rotten and sprouted.

The tuber rotten evidence could be triggered by activity of respiration process degrading organic material so that the tubers lose the organic compounds and be rotted. As the length of storage time, an increament of the percentage of rotten tubers was also followed by the percentage of sprouting tubers. Sprouted tubers occured when the rotten area appeared in the

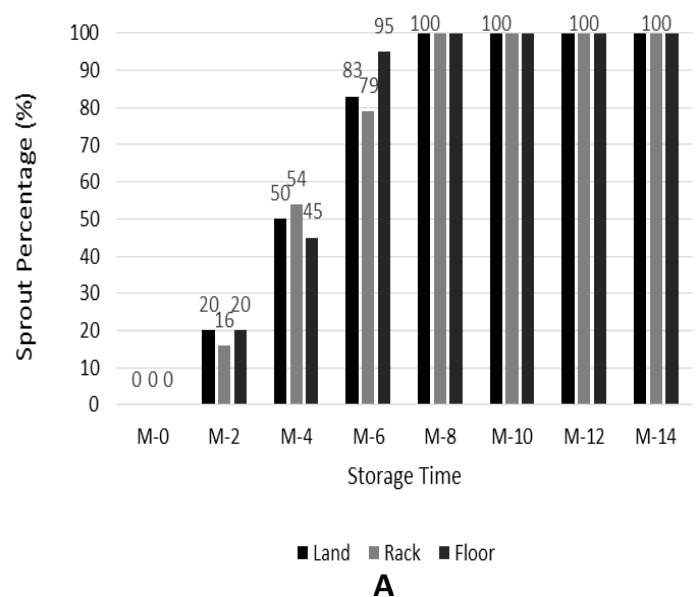

partial side of the tuber. Physiological processes took place as the respiration process conducted then produced energy used for sprouting.

Sprout growth faster at room temperature than cold temperatures, because the respiration process is increasing in the higher temperature [17]. Rotten in the tubers can occur due to the natural conditions of the tuber, handling during growth and postharvest. Several factors causing penetration microorganisms could be a) before harvesting, through pores that exist naturally in parts of plants that allow air, carbon dioxide, and water vapour to enter and exit the commodity network; b) Postharvest damage due to wrong handling, so that the wound can cause microorganisms to penetrate into the tuber; c) The entry of microorganisms directly due to contact with tuber skin tissue, where these conditions are influenced by the type of commodity, the level of maturity and the type of microbe's direct contact. This can occur either before or after harvesting, which may not appear directly but can occur at any time either during storage or when it reaches the consumer [18].

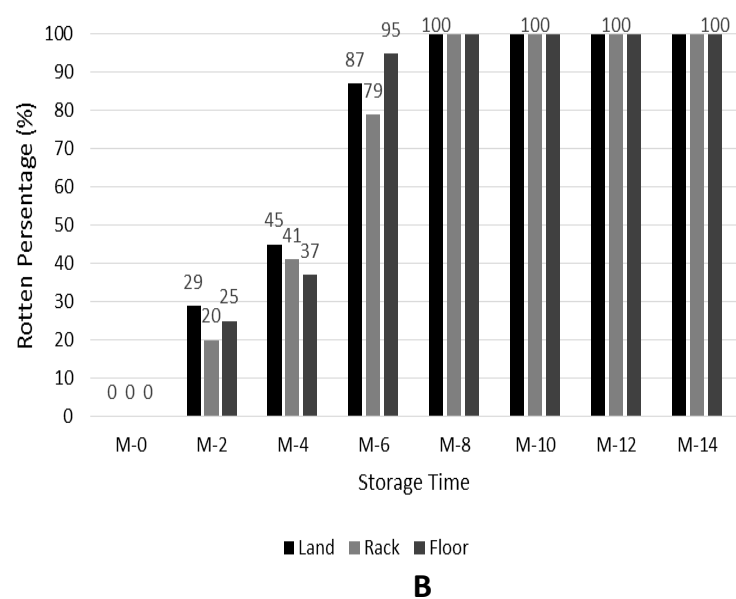

Figure 5. (A) Sprout percentage (\%) and (B) Rotten percentage (\%) during the storage period for each storage place

As comparation, in the case of white yam (Dioscorea rotundata), their growth were increasing on three storage methods (tubers stacked on the floor, traditional barns and open storage side) but they did not show significant differences [15]. Rot on the white yams began to appear at the twelfth week in all three storage areas, storage on the open side was the lowest rot rate (10\%). The storage method with tubers stacked on the floor had the highest level of rot rate $(26.67 \%)$. However, the white yam stored in traditional barns did not differ from the two storage methods.

\section{Weight loss and water content (\%)}

The length of storage caused weight loss of the tuber. The water content of the tuber fluctuated, but overall the moisture content of the tubers during storage tended to decrease (Fig. 6). The phenomenon could be initiated by increasing respiration rate. For the tubers stored in the soil, the rotten tuber might be accelareted by cell degradation faster into the soil. During storage, the rotten tuber became dry as the water content of Porang tubers decreases. 


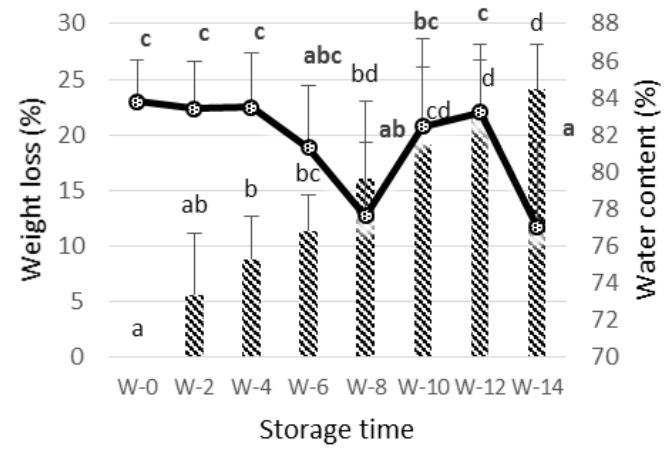

www Weight loss $\quad-\Theta-$ Water content

Figure 6. Weight loss and water content during storage.

Description: Lowercase notation to compare between storage periods. The line on the beam shows the Standard Deviation (SD) at $\alpha 0.05$.

The weight loss might be caused by loss of water in the transpiration process. If the tubers stored for a long time, it causes a decrease on water content, so it gradually undergoes shrinkage $[19,20]$. The porang tubers was also shrinkage during storage. The process of transpiration causes water levels to-decrease. While the process of respiration that produces water causes an increase in water content this may reason that the water content during storage fluctuates.

Water is the most important component of cells where its function is to carry out the function of cell life which includes metabolic reactions and distribution of nutrients to all parts of the organ. The water contained in tubers is in the form of crystallization of water or colloidal water. Some other water is called free water which is a solvent for the hydrophilic compounds found in the tubers. The water content in fresh tubers is $83.3 \%$ wet weight $[21,22]$. Moisture and weight loss are related to the physiological mechanism of the postharvest rotten tuber. Tubers that are stored on the ground exhibit foul symptoms faster in the form of significant weight shrinkage, decreasing in density and moisture content. The symptoms got faster may be caused the soil contains many microorganisms that can infect the tubers and can reduce the quality of the tubers [23].

Weight loss in tubers causes shrinkage, which is one of the criteria for quality standards for agricultural products. Weight loss is a main indicator in quality decrease including changes in appearance, texture, nutritional value of the product, and affects to decrease the selling price of tubers [8]. The respiration, transpiration, and sprouting are the factors responsible for weight loss and influence the appearance and cause tubers to shrivel [15].

Previous research also showed that the value of water content during storage time was not significantly different, but there was a tendency that the water content was decreasing during the period of storage. The transpiration could increase as the increase of the temperature [5]. The same thing also applies to sweet potato research during storage, the moisture content at the beginning of storage was $65.71 \%$ and decreases in a row for treatment in the tarpaulin base space, in a sawdust sprinkling box, in a plastic-straw pile base, and in the soil the pile of straw-sand pile were 58.96\%, 59.71\%, 61.36\% and $61.5 \%$ [24].

Sweet potatoes showed shrinkage of weight during storage. the highest shrinkage happened at room temperature compared to cold temperature storage. At eight weeks the weight loss composition of Gisting sweet potatoes reached $16.87 \%$ for storage space, while in cold storage shrinkage weight was only $10.12 \%$. The same thing also happened in Marga sweet potatoes in the storage of the room shrinkage reached $19.84 \%$ while at cold shrinkage the weight reached $14.66 \%$ [17]. There was a striking decrease in the number of amyloplast cells observed during the initial stages of shoot formation. This symptom of weight loss in tubers during storage is most likely also related to the occurrence of sprouts $[5,25]$.

\section{CONCLUSION}

The porang tuber have begun to show a decline in quality since two weeks stored. This decrease in quality was performed by symptoms of rotten indicated by the appearance of odor, decreasing in tuber weight, followed by a decrease in water content, an increase of rotten tuber area, and a percentage increment in rotten area and sprout of tuber. The storage place that slows decay most was on the shelf compared to those on the soil and the floor.

\section{REFERENCES}

[1] Wootton, N.A., M. Luker-Brown., R.J. Westcott. 1993. The extraction of a glucomannan polysaccharide from konjac corms (elephant yam, Amorphophallus rivierii). J. Sci. Food Agric. 61. 429-433.

[2] Indonesian Research and Development Center of Porang (P4I). 2013. Modul diseminasi: budidaya dan pengembangan 
porang (Amorphophallus muelleri Blume) sebagai salah satu potensi bahan baku lokal. University of Brawijaya. Malang.

[3] Indonesian National Standar (SNI) 7938: 2013. Umbi Porang. Badan Standardisasi Nasional.

[4] Amponsah, S.K., J.O. Akowuah., E.A. Kwarteng., E. Bessah. 2015. Design and construction of improved yam storage structure using locally-available materials. Int. J. Res. Agr. For. 2. 1-11.

[5] Asgar, A., S.T. Rahayu. 2014. Pengaruh suhu penyimpanan dan waktu pengkondisian untuk mempertahankan kualitas kentang kultivar margahayu. Berita Biologi. 13(3). 283-293.

[6] Ali, M.G., S. Houshmand. 2010. Effects of mechanical damage and temperature on potato respiration rate and weight loss. World Appl. Sci. J. 8(5). 647-652.

[7] Kibar, H. 2012. Design and management of postharvest potato (Solanum tubrosum L.) storage structures. J. Sci. Tech. 2(1). 23-48.

[8] Sudarmadji, S., B. Haryono, Suhadi. 1997. Analisa bahan makanan dan pertanian. Liberty. Yogyakarta.

[9] Zhao, J., D. Zhang., G. Srzednicki., S. Kanlayanarat., C. Borompichaichartkul. 2010. Development of a low-cost two-stage technique for production of low-sulphur purified konjac flour. Int. Food Res. J. 17. 1113-1124.

[10] Homaida, M.A., S. Yan., H. Yang. 2017. Effects of ethanol treatment on inhibiting fresh-cut sugarcane enzymatic browning and microbial growth. LWT-Food Sci. Technol. 77. 8-14.

[11] Richana, N., T.C. Sunarti. 2004. Karakterisasi sifat fisikokimia tepung umbi dan tepung pati dari umbi ganyong, suweg, ubikelapa dan gembili. Jurnal Pascapanen. 1(1). 29-37.

[12] Friedman, M. 1996. Food browning and its prevention: an overview. J. Agric. Food Chem. 44(3). 631-653.

[13] Purwantisari, S., R.S. Ferniah., B. Raharjo. 2008. Pengendalian hayati penyakit lodoh (busuk umbi kentang) dengan agens hayati jamur-jamur antagonis isolat lokal. Bioma 2. 13-19.

[14] Handayani, A., Sriyanto., I. Sulistyawati. 2013. Evaluasi mutu beras dan tingkat kesesuaian penanganannya (studi kasus di kabupaten Karanganyar). Jurnal Litbang Provinsi Jawa Tengah. 11(1). 113-124.
[15] Maalekuu, B.K., J.K. Saajah., A.K. Addae. 2014. Effect of three storage methods on the quality and shelf-life of white yam (Dioscorea rotundata) cultivars pona and tela. J. Agr. Sci. 6(7). 221-230.

[16] Ray, R.C. 2000. Microorganism associated with post harvest spoilage of yams. Ann. Trop. Res. 22. 31-40.

[17] Narulita, A., S. Waluyo, D.D. Novita. 2013. Sifat fisik ubi jalar (jalar gisting kabupaten Tanggamus dan jati agung kabupaten Lampung Selatan) pada dua metode penyimpanan. Jurnal Teknik Pertanian Lampung. 2(3). 133-146.

[18] Estiasih, T., W.D.R. Putri., E. Waziiroh. 2017. Umbi-umbian dan pengolahannya. University of Brawijaya Press. Malang.

[19] Osunde, Z.D., B.A. Orhevba. 2009. Effects of storage conditions and storage period on nutritional and other qualities of stored yam (Discorea spp) tubers. Af. J. Food Agr. Nutr. Dev. 9(2). 679-690.

[20] Senkumba, J., A. Kaaya., A. Atukwase., A. Wasukira. 2017. Technical report: effect of storage conditions on the processing quality of different potato varieties grown in Eastern Uganda. Research program on root, tubers, and bananas. Uganda.

[21] Lisinska, G., W. Leszczynski. 1989. Potato science and technology. Elsevier Publication. Essex.

[22] Arifin, A.M. 2001. Pengeringan umbi iles-iles secara mekanik untuk meningkatkan mutu keripik iles. Master Thesis. Postgraduate School, Bogor Agricultural University. Bogor.

[23] Ogunleye, A.O., O.T. Ayansola. 2014. Studies of Some Isolated Rot-Causing Mycoflora of Yams (Dioscorea spp.). Am. J. Microbiol. Biotech. 1(1). 9-20.

[24] Kafiya, M., Sutrisno., R. Syarief. 2016. Perubahan kadar air dan pati ubi jalar (Ipomea batatas L.) segar pada sistem penyimpanan sederhana. Jurnal Penelitian Pascapanen Pertanian. 3(3). 136-145.

[25] Chua, M. 2011. An investigation of the biology and chemistry of the chinese medical plant, Amorphophallus konjac. Ph.D Thesis. University Of Wolverhampton. 